\title{
Antibiofilm, Antioxidant, Antimutagenic Activities and Phenolic Compounds of Allium orientale BOISS.
}

\author{
Ozgur Ceylan* and Halime Alıc \\ ${ }^{I}$ Mugla University - Apiculture; Ula Ali Kocman Vocational School Mugla Sitki Kocman University;, Mugla - \\ Turkey. ${ }^{2}$ Mugla Sitki Kocman University - Biology; Mugla - Turkey
}

\begin{abstract}
This is the first study to investigate the antibiofilm, antioxidant and antimutagenic activities and phenolic compounds of Allium orientale. Antimicrobial activity of ethanolic extracts of A. orientale was determined by a broth microdilution method. Antibiofilm activity was evaluated by microplate biofilm assay. The antioxidant activity was determined using three complementary assays; namely, DPPH scavenging, $\beta$-carotene-linoleic acid, and total phenolic compounds assays. Phenolic compounds were evaluated by reverse-phase high-performance liquid chromatography. The antimutagenic effect of extracts was analyzed by the Ames test. In RP-HPLC analysis, (+)catechin, apigenin and caffeic acid were identified as major phenolic compounds in the aerial parts of A. orientale. The aerial parts extract possessed the highest total phenolic content (120.979 $\pm 1.05 \mathrm{mg}$ gallic acid equivalent/g), which were in good correlation with its significant DPPH (IC50 $42.18 \pm 1.68 \mathrm{mg} / \mathrm{mL})$ and lipid peroxidation (89.98 $\pm 0.69 \%$ at $10 \mathrm{mg} / \mathrm{mL}$ concentration) capacities. A. orientale exhibited potent antimicrobial activity against the organisms tested with MICs ranging from 3.125 to $25 \mathrm{mg} / \mathrm{mL}$. Escherichia coli biofilm formation was inhibited maximum by the aerial parts extract to an extent of $68.51 \%$. The strongest antimutagenic activity was observed at $2.5 \mathrm{mg} /$ plate concentration of aerial parts extract against Salmonella typhimurium TA98.These results suggested that the ethanolic extract of the aerial parts of A.orientale could become useful supplement for pharmaceutical products as a new antioxidant, antibiofilm and antimutagenic agent.
\end{abstract}

Key words: Allium orientale, Antibiofilm activity, Antimutagenic activity, Antioxidant activity, Phenolic compounds

\section{INTRODUCTION}

Depending on rapid urbanization, changes in the life styles and dietary habits cause many diseases (Tapsell et al. 2006). Due to their beneficial properties, a large number of medicinal plants and their purified constituents are used for the prevention and treatment of complex diseases, such as cancer, cardiovascular diseases and diabetes (Boffetta et al. 2010; Bernaert et al. 2012; Dziri et al. 2012). The biological effects of the plants are mainly due to the presence of various bioactive components, such as antioxidants, including phenolics, vitamins, organo-sulfur compounds, volatile sulfur compounds, fatty acids and tocopherols (Ames et al. 1993; CorzoMartinez et al. 2007; Bernaert et al. 2012; RouisSoussi et al. 2014). Because of potential health benefits and nutritional values, the Allium species, especially onion and garlic have been used in the daily diet by the majority of the world's population (Iciek et al. 2009; Dziri et al. 2012). There are several studies reporting the important roles of the members of the genus in the prevention and treatment of pathogenic infections, cancers and cardiovascular diseases (Lau 2006;

*Author for correspondence: ozgceylan@ hotmail.com 
Yeh and Yeh 2006; Islam et al. 2011; Dziri et al. 2012). Investigations dealing with Allium species have shown that their beneficial properties are associated with the chemical contents. In particular, bioactive constituents namely organosulfur compounds (alliin and $\gamma$-glutamylcysteine), volatile sulfur compounds (diallyl sulfide, diallyl disulfide etc.), proteins (lectins), prostaglandins, fructan, vitamins (B1, B2, B6, C and E), polyphenols, fatty acids, and essential oils have been identified in chemical investigations of Allium species (Corzo-Martinez et al. 2007; Dziri et al. 2012). Among the mentioned constituents, especially polyphenols have been subjected to many studies regarding to their antioxidant, antimicrobial, antifungal, cytotoxic and mutagenic activities (Redzic et al. 2008; Lazarevic et al. 2011; Karuppiah and Rajaram 2012; Simin et al. 2013; Timite et al. 2013; Rezgui et al. 2014; Rouis-Soussi et al. 2014). Besides their medicinal importance, they have an economic value, depending on their usage in perfume and cosmetic industries, and cultivation as an ornamental plant.

The Allium genus (Liliaceae) is widespread in the northern hemisphere and has species diversity. In the northern hemisphere, 700 species have been described as belonging to Allium genus (Tepe et al. 2005) and 168 of these are available in Turkish flora (Eker and Koyuncu 2011). However, 65 species have been reported as endemic to Turkey (Davis 1984; Guner et al. 2000; Tepe et al. 2005). Studies on the genus have focused on well-known species, A. cepa (onion) and A. sativum (garlic). However, a few studies have assessed the chemical and biological properties of other species. A. orientale Boiss is bulbous perennial plant, native from the North Africa to West Asia. A. orientale with the other six taxon (A. nigrum L., A. cyrilli Ten.(three subspecies), A. elmaliense and A. lycaonicum) have been reported in central and western Anatolia (Genc and Ozhatay 2014). In Turkey, A. orientale grows in limestone hills and slopes, rocky places, fields and vineyards between 600 and 1870 meters (Davis 1984). The flowers are hermaphrodite and pollinated by bees and insects. It prefers light (sandy), medium (loamy) and well-drained soils (PFAF). Investigations dealing with $A$. orientale are scarce. Recently, several studies have been done about the distribution areas of $A$. orientale in certain regions of Turkey. However, until now, there is no report describing the antibiofilm, antioxidant, antimutagenic activities and phenolic compounds of $A$. orientale. Thus, the present study intended to: (a) assess the antimicrobial and antibiofilm activities against five microorganisms by using a broth microdilution method and microplate biofilm assay, respectively; (b) evaluate the antioxidant activities of ethanolic extracts by using three complementary in vitro assays: free radical scavenging activity (DPPH assay), $\beta$-carotenelinoleic acid method, and total phenolic compounds determination; (c) characterize the phenolic profiles of aerial parts and bulbs by reversed-phase high-performance liquid chromatography (RP-HPLC); (d) investigate the mutagenic and antimutagenic activities by Ames Salmonella/microsome mutagenicity test.

\section{MATERIAL AND METHODS}

\section{Plant Material}

The aerial parts and bulbs of Allium orientale BOISS, naturally growing plants belonging to the Liliaceae family were collected from Mugla, Turkey. The plant samples were identified by Mehtap Donmez Sahin and the voucher specimen has been deposited in the Herbarium of The Faculty of Education, University of Usak under acquisition number 1603. In the laboratory, the plant samples were air-dried at room temperature for later analysis.

\section{Preparation of the ethanolic extract}

The air-dried and powdered plant samples were extracted with ethanol (Merck) using the Soxhlet apparatus. The extract was evaporated and then extracted in ethanol/water $(1: 1, \mathrm{v} / \mathrm{v})$, and then kept in small sterile opaque bottles under refrigerated conditions until used.

\section{Microorganisms}

The in vitro antimicrobial activity of the ethanol extracts of $A$. orientale was tested against a panel of laboratory control strains from the American Type Culture Collection, Staphylococcus aureus ATCC 25923 and Bacillus subtilis ATCC 6633 (Gram-positive bacteria), Escherichia coli ATCC 25922 and Pseudomonas aeruginosa ATCC 27853 (Gram-negative bacteria) and Candida albicans ATCC 10239. All the microorganisms were maintained at $-20^{\circ} \mathrm{C}$ under appropriate conditions and regenerated two times before use.

Salmonella typhimurium TA98 and $S$. typhimurium TA100 were used for the mutation 
studies and antimutagenicity tests. The strains were analyzed for their histidine and biotin requirement, individually and in combination, rfa mutation, excision repair capability, presence of the plasmid pKM101, and spontaneous mutation rate according to Mortelmans and Zeiger (2000). Working cultures were prepared by inoculating nutrient broth with the frozen cultures, followed by an overnight incubation at $37^{\circ} \mathrm{C}$ with gentle agitation (Oh et al. 2008).

\section{Determination of MICs}

MICs for bacteria were determined by a broth microdilution method with Mueller-Hinton Broth (CLSI 2006). Sabouraud Dextrose Broth was used for $C$. albicans. The density of microorganisms was $5 \times 10^{5}$ colony-forming units $(\mathrm{CFU}) / \mathrm{mL}$. Cell suspensions $(200 \mu \mathrm{L})$ were inoculated into the wells of 96-well microtitre plates (Nunc F96 MicroWell ${ }^{\mathrm{TM}}$ plates; NunclonTM $\Delta$, Denmark) in the presence of extracts with different final concentrations $(0.78,1.56,3.12,6.25,12.5,25,50$ $\mathrm{mg} / \mathrm{mL}$ ). Gram-negative bacteria and C. albicans were incubated at $30^{\circ} \mathrm{C}$ for $18-24 \mathrm{~h}$ and $24-48 \mathrm{~h}$, respectively. Other bacterial strains were incubated at $37^{\circ} \mathrm{C}$ for $24 \mathrm{~h}$. The MIC was defined as the lowest concentration of extract at which no visible growth was observed.

\section{Effect on biofilm formation}

The effect of $A$. orientale extract at concentrations including $1,1 / 2,1 / 4$ and $1 / 8$ MIC on biofilm-forming ability of test microorganisms were tested with a microplate biofilm assay (Merritt et al. 2005). Briefly, $1 \%$ of overnight cultures of test pathogens were added into $200 \mu \mathrm{L}$ of fresh TSB supplemented with $0.25 \%$ glucose and cultivated in the presence and absence of extracts without agitation at $37^{\circ} \mathrm{C}$ for $48 \mathrm{~h}$. The wells containing only TSB+cells served as control. After incubation, the wells were washed with water to remove the planktonic bacteria. The remaining bacteria were subsequently stained with $0.1 \%$ crystal violet solution for $10 \mathrm{~min}$ at room temperature. Wells were washed once again to remove the crystal violet solution. Microplates inverted and vigorously tap on paper towels to remove any excess liquid and air-dried. Two hundred microliters of $95 \%$ ethanol and $33 \%$ glacial acetic acid (Sigma Chemical Co) were poured in Gram-negative bacterial/C. albicans wells and Gram-positive bacterial wells, respectively. After shaking and pipetting of the wells, $125 \mu \mathrm{L}$ of the solution from each well was transferred to a sterile tube and volume reached to $1.0 \mathrm{~mL}$ with distilled water. Finally, optical density (OD) of each tube was measured at 550 nm (Thermo Scientific Multiskan FC, Vantaa, Finland). Each strain was tested for biofilm production in duplicate and the assay was repeated three times. Replicate absorbance readings for each concentration tested were averaged and the average of the media control was subtracted. This value was then divided by the mean absorbance of the (cell+TSB) and multiplied by 100 .

\section{Antioxidant activity DPPH assay}

The free radical scavenging activity was performed using the 1,1-diphenyl-2-picryl hydrazyl (DPPH) assay (Yamasaki et al. 1994). For this, $5.0 \mu \mathrm{L}$ of the extract $\{1.25,2.5,5.0$ and $10 \mathrm{mg} / \mathrm{mL}$ in ethanol/water $(1: 1, \mathrm{v} / \mathrm{v})\}$ was added to $4995 \mu \mathrm{L}$ DPPH solution $(0.004 \%)$ in ethanol. After incubation at room temperature for $30 \mathrm{~min}$, the absorbance of each solution was determined at $517 \mathrm{~nm}$. Percentage of inhibitions and the concentrations of sample required for $50 \%$ scavenging of the DPPH free radical $\left(\mathrm{IC}_{50}\right)$ were determined. BHT and ascorbic acid were used as positive controls.

\section{$\beta$ - carotene-linoleic acid method}

The total antioxidant activity of the extracts was evaluated by the $\beta$-carotene-linoleic acid model (Jayaprakasha and Jaganmohan Rao 2000). For this, $0.5 \mathrm{mg}$ of the $\beta$-carotene in $1.0 \mathrm{~mL}$ of chloroform, $25 \mu \mathrm{L}$ of linoleic acid and $200 \mathrm{mg}$ of Tween-40 (polyoxyethylene sorbitan monopalmitate) were mixed together. The chloroform was completely evaporated using a vacuum evaporator and the resulting solution was diluted with $100 \mathrm{~mL}$ of oxygenated water. A 2.5 $\mathrm{mL}$ aliquots of this mixture were transferred into different tubes containing $0.5 \mathrm{~mL}$ of samples at $3.15 \mathrm{mg} / \mathrm{mL}$ concentration in ethanol/water $(1: 1$, $\mathrm{v} / \mathrm{v})$. The same procedure was repeated with the positive control BHT, ascorbic acid, and a blank. The emulsion system was incubated for up to $2 \mathrm{~h}$ at $50^{\circ} \mathrm{C}$. Measurement of the absorbance was continued until the color of $\beta$-carotene disappeared in the control. After this incubation period, absorbance of the mixtures was measured at 490 $\mathrm{nm}$. All the determinations were performed in triplicate. 
The bleaching rate (R) of $\beta$-carotene was calculated using the following formula. $\mathrm{R}=\ln (\mathrm{a} / \mathrm{b}) /$ $\mathrm{t}$ where, $\ln =$ natural $\log , \mathrm{a}=$ absorbance at time 0 , $\mathrm{b}=$ absorbance at time $\mathrm{t}(120 \mathrm{~min})$.

The antioxidant activity (AA) was calculated in terms of percent inhibition relative to the control using the formula $\mathrm{AA}=\left[\left(\mathrm{R}_{\mathrm{Control}^{-}}\right.\right.$ $\left.\left.\mathrm{R}_{\text {Sample }}\right) / \mathrm{R}_{\text {Control }}\right] \times 100$. Antioxidative activity of the extracts was compared with those of BHT and ascorbic acid at $0.5 \mathrm{mg} / \mathrm{mL}$.

\section{Determination of total phenolic compounds}

The phenolic constituent of the extracts were determined by the method involving the FolinCiocalteu reagent and gallic acid as a standard (Slinkard and Singleton 1977; Chandler and Dodds 1983). Two hundreds microliter of extract solution containing $0.1 \mathrm{mg}$ extract was added to a test tube. Then, $100 \mu \mathrm{L}$ Folin-Ciocalteu reagent was added and tube was shaken vigorously. After $3 \mathrm{~min}, 2 \mathrm{~mL}$ solution of $\mathrm{Na}_{2} \mathrm{CO}_{3}(0.5 \%)$ was added and the mixture was allowed to stand for $2 \mathrm{~h}$ with intermittent shaking. Absorbance was measured at $760 \mathrm{~nm}$. Content of phenolic compounds was determined as mg gallic acid equivalents per gram of extract (mg/g GAE extract) using the following linear equation based on the calibration curve: $\mathrm{A}=$ $0.0257 \mathrm{C}, \mathrm{R} 2=0.997$ where $\mathrm{A}$ was the absorbance and $\mathrm{C}$ gallic acid equivalents.

\section{Quantification of phenolic compounds by RP- HPLC}

Phenolic compounds were evaluated by reversedphase high-performance liquid chromatography (RP-HPLC, Shimadzu Scientific Instruments, Tokyo, Japan). Detection quantification was carried out with a LC-10ADvp pump, a Diode Array Detector, a CTO 10Avp column heater, SCL-10Avp system controller, DGU-14A degasser and SIL-10ADvp auto sampler (Shimadzu Scientific Instruments, Columbia, MD). Separations were conducted at $30^{\circ} \mathrm{C}$ on Agilent ${ }^{\circledR}$ Eclipse XDB C-18 reversed-phase column (250 $\mathrm{mm} \times 4.6 \mathrm{~mm}$ length, $5 \mu \mathrm{m}$ particle size). The eluates were detected at $278 \mathrm{~nm}$. The mobile phases were A: $3.0 \%$ acetic acid in distilled water and B: methanol. For analysis, the samples were dissolved in ethanol: bidistilled water $(1: 1, \mathrm{v} / \mathrm{v})$, and $20 \mu \mathrm{L}$ of this solution was injected into the column.

The elution gradient applied at a flow rate of 0.8 $\mathrm{mL} \mathrm{min}^{-1}$ was: $93 \% \mathrm{~A} / 7 \% \mathrm{~B}$ for $0.1 \mathrm{~min}$, $72 \% \mathrm{~A} / 28 \% \mathrm{~B}$ in $20 \mathrm{~min}, 75 \% \mathrm{~A} / 25 \% \mathrm{~B}$ in $8 \mathrm{~min}$,
$70 \% \mathrm{~A} / 30 \% \mathrm{~B}$ in $7 \mathrm{~min}$ and same gradient for 15 $\mathrm{min}, 67 \% \mathrm{~A} / 33 \% \mathrm{~B}$ in $10 \mathrm{~min}, 58 \% \mathrm{~A} / 42 \% \mathrm{~B}$ in 2 $\min , 50 \% \mathrm{~A} / 50 \% \mathrm{~B}$ in $8 \mathrm{~min}, 30 \% \mathrm{~A} / 70 \% \mathrm{~B}$ in 3 min, $20 \% \mathrm{~A} / 80 \% \mathrm{~B}$ in $2 \mathrm{~min} 100 \% \mathrm{~B}$ in 5 min until the end of the run. Phenolic compositions of the extracts were determined by a modified method of Caponio et al. (1999). Protocatechuic acid, (+)catechin, p-hydroxy benzoic acid, chlorogenic acid, caffeic acid, (-)-epicatechin, benzoic acid, rosmarinic acid, ferulic acid and apigenin were used as standard. Identification and quantitative analysis were done by comparison with the standards. The amount of each phenolic compound was expressed as mg per gram of extract.

\section{Mutagenic and antimutagenic activity Viability assays and determination of test concentrations}

Cytotoxic doses of the extracts were determined by the method of Mortelmans and Zeiger (2000). The toxicity of the extract toward S. typhimurium TA98 and TA100 was determined as described by Santana-Rios et al. (2001) and Yu et al. (2001). These tests confirmed that there was normal growth of the background lawn, spontaneous colony numbers within the regular range, and no significant reduction in cell survival. Thus, for the concentrations and conditions reported here, no toxicity or other adverse effects were observed.

\section{Mutagenicity and antimutagenicity tests}

In this study, the plate incorporation method was used to assess the results of mutagenicity and antimutagenicity assays (Maron and Ames 1983). The 4- nitro-o-phenylenediamine (4-NPD) at 3.0 $\mu \mathrm{g} /$ plate for $S$. typhimurium TA98 and sodium azide $\left(\mathrm{NaN}_{3}\right)$ (8 $\left.\mu \mathrm{g} / \mathrm{plate}\right)$ for $S$. typhimurium TA100 were used as positive controls and ethanol/ water $(1: 1, \mathrm{v} / \mathrm{v})$ was used as a negative control in mutagenicity and antimutagenicity tests.

In the mutagenicity test performed with TA98 and TA100 strains of $S$. typhimurium, $100 \mu \mathrm{L}$ of the overnight bacterial culture, $100 \mu \mathrm{L}$ test compounds at different concentrations $(2.5,1.25$ and 0.625 $\mathrm{mg} /$ plate), and $500 \mu \mathrm{L}$ phosphate buffer were added to $2.0 \mathrm{~mL}$ of the top agar containing 0.5 $\mathrm{mM}$ histidine/biotin. The mixture was poured onto minimal glucose plates. Histidine independent revertant colonies and viable cells were scored on the plates after incubation at $37^{\circ} \mathrm{C}$ for 48 or $72 \mathrm{~h}$. For the mutagenicity assays, the mutagenic index was calculated for each concentration, which was the average number of revertants per plate divided 
by the average number of revertants per plate with the negative control

In the antimutagenicity test performed with the same strains, $100 \mu \mathrm{L}$ of the overnight bacterial culture, $100 \mu \mathrm{L}$ mutagen, $100 \mu \mathrm{L}$ test compounds at different concentrations $(2.5,1.25$ and 0.625 $\mathrm{mg} /$ plate), and $500 \mu \mathrm{L}$ phosphate buffer were added to $2.0 \mathrm{~mL}$ of the top agar containing 0.5 $\mathrm{mM}$ histidine/biotin. The mixture was poured onto minimal glucose plates. Histidine independent revertant colonies and viable cells were scored on plates after incubation at $37^{\circ} \mathrm{C}$ for 48 or $72 \mathrm{~h}$.

For the antimutagenicity assays, the inhibition of mutagenicity was calculated by using the following equation (M: number of revertants/plate induced by mutagen alone, $S_{0}$ : number of spontaneous revertants, $\mathrm{S}_{1}$ : number of revertants/plate induced by the extract plus the mutagen $): \%$ Inhibition $=\left[\left(\mathrm{M}-\mathrm{S}_{1}\right)-\left(\mathrm{M}-\mathrm{S}_{0}\right)\right] \times 100$. $25-40 \%$ inhibition was defined as moderate antimutagenicity; $40 \%$ or more inhibition as strong antimutagenicity; and $25 \%$ or less inhibition as no antimutagenicity (Ikken et al. 1999; Negi et al. 2003; Evandri et al. 2005).

\section{Statistical analysis}

All of the experimental results were as mean \pm SD of three parallel measurements. The data was entered into a Microsoft Excel database and analyzed using SPSS. The $\mathrm{IC}_{50}$ values were obtained by the linear regression analysis. Statistical analysis of the total antioxidant activity was performed using the Kruskal-Wallis test.

\section{RESULTS AND DISCUSSION}

Minimum inhibitory concentrations of $A$. orientale extracts were determined by a broth microdilution method. As shown in Table 1, MIC values of bulb ethanolic extract ranged between 6.25 and 25 $\mathrm{mg} / \mathrm{mL}$, whereas the aerial part extract showed the lowest MIC for both the microorganisms, namely, B. subtilis ATCC 6633 and C. albicans ATCC 10239. The aerial parts extract showed the MIC values of $3.125 \mathrm{mg} / \mathrm{mL}$ against $B$. subtilis ATCC 6633 and C. albicans ATCC 10239 while bulb extract showed the MIC values of 12.5 and 6.25 $\mathrm{mg} / \mathrm{mL}$, respectively against the same reference strains.

Aerial part extracts exhibited MIC values against S. aureus ATCC $25923(6.25 \mathrm{mg} / \mathrm{mL})$ and both Gram- negative bacteria ( $P$. aeruginosa ATCC 27853 and E. coli ATCC 25922) $(12.5 \mathrm{mg} / \mathrm{mL})$. On the other hand, the bulb extract inhibited $S$. aureus ATCC 25923 with MIC value of 12.5 $\mathrm{mg} / \mathrm{mL}$ and Gram-negative bacteria with MIC value of $25 \mathrm{mg} / \mathrm{mL}$. MIC results showed that the aerial part extract had higher antimicrobial activity than the bulb's extract. Phenolic compounds possess a considerable antimicrobial capacity against a very large number of human pathogens (Tepe et al. 2005). The relatively higher antimicrobial activity of the aerial parts extract could be indicative for the presence of some phenolic compounds such as (+)-catechin, apigenin and caffeic acid.

Table 1 - Minimum inhibitory concentrations and antibiofilm activities of A. orientale ethanol extracts against pathogen bacteria.

\begin{tabular}{llcllll}
\hline \multirow{2}{*}{ Microorganism } & \multirow{2}{*}{ Extract } & \multicolumn{2}{l}{ Planktonic } & \multicolumn{2}{l}{ Biofilm inhibitory activity (\% inhibition) } \\
\cline { 3 - 7 } & & $\begin{array}{l}\text { MIC } \\
(\mathbf{m g} / \mathbf{m L})\end{array}$ & MIC & MIC/2 & MIC/4 & MIC/8 \\
\hline B.subtilis ATCC 6633 & Aerial parts & 3.125 & $31.63 \pm 5.49$ & $13.48 \pm 1.53$ & - & - \\
& Bulbs & 12.5 & $55.24 \pm 3.31$ & $35.91 \pm 1.66$ & $26.51 \pm 1.32$ & $12.98 \pm 1.94$ \\
S.aureus ATCC 25923 & Aerial parts & 6.25 & $13.81 \pm 0.49$ & $7.83 \pm 0.7$ & $3.29 \pm 0.22$ & - \\
& Bulbs & 12.5 & $44.12 \pm 2.2$ & $21.24 \pm 1.09$ & $8.77 \pm 0.7$ & - \\
P.aeruginosa ATCC 27853 & Aerial parts & 12.5 & $45.63 \pm 7.23$ & $32.13 \pm 2.58$ & $8.73 \pm 1.25$ & - \\
& Bulbs & 25 & $39.11 \pm 2.89$ & $13.16 \pm 1.65$ & - & - \\
E.coli ATCC 25922 & Aerial parts & 12.5 & $68.51 \pm 7.94$ & $37.24 \pm 6.26$ & $8.78 \pm 3.1$ & - \\
& Bulbs & 25 & $31.18 \pm 2.82$ & $10.32 \pm 1.27$ & - & - \\
C.albicans ATCC 10239 & Aerial parts & 3.125 & $24.59 \pm 8.2$ & $4.9 \pm 1.1$ & - & - \\
& Bulbs & 6.25 & $24.04 \pm 2.3$ & $6.01 \pm 0.75$ & - & - \\
\hline
\end{tabular}

Although antimicrobial activities of some Allium species have already been reported (Hannan et al. 2010; Najjaa et al. 2011; Ismail et al. 2013; Bakht et al. 2014), little attention was paid to their antibiofilm potential (Nidadavolu et al. 2012; Ceylan 2014). In the antibiofilm quantification 
assay, a concentration dependent decrease in biofilm formation was observed in the test microorganisms when treated with the ethanol extracts of A. orientale. E. coli ATCC 25922 was maximally inhibited by the aerial parts extract at a concentration of $12.5 \mathrm{mg} / \mathrm{mL}$ to an extent of $68.51 \%$. This ratio was $31.18 \%$ on the same bacteria biofilm formation at MIC of bulb extract. At a concentration of $12.5 \mathrm{mg} / \mathrm{mL}$, the bulb's extract (MIC), the mean biofilm formation value was equal to $55.24 \%$ for B. subtilis ATCC 6633 . The antibiofilm activity of aerial parts extract on B. subtilis ATCC 6633 biofilm formation was observed lower than bulb extract. However, antibiofilm activity results showed that the bulb extract had less effect on biofilms compared with the aerial parts extract.

Antioxidant activities of $A$. orientale ethanol extracts, standard BHT and ascorbic acid are presented in Table 2. In this, lower $\mathrm{IC}_{50}$ values indicated higher antioxidant activity. The extracts of the aerial parts and the extract of the bulbs reduced the stable free-radical DPPH with an $\mathrm{IC}_{50}$ of 42.18 and $148.86 \mathrm{mg} / \mathrm{mL}$ whereas $\mathrm{IC}_{50}$ of standard BHT and ascorbic acid were lower at 0.95 and $0.48 \mathrm{mg} / \mathrm{mL}$, respectively. DPPH test results were in good agreement with previous studies results, which showed that the aerial parts extract provided higher free radical scavenging than the bulb extract (Stajner et al. 2008; Nencini et al. 2011; Rouis-Soussi et al. 2014).

Table 2 - DPPH radical-scavenging activity of $A$. orientale extracts.

\begin{tabular}{lc}
\hline Sample & IC $_{\mathbf{5 0}}$ value $^{\mathbf{a}}(\mathbf{m g} / \mathbf{m L})$ \\
\hline The extract of the aerial parts & $42.18 \pm 1.68$ \\
The extract of the bulbs & $148.86 \pm 0.62$ \\
BHT & $0.95 \pm 0.014$ \\
Ascorbic acid & $0.48 \pm 0.019$ \\
\hline
\end{tabular}

${ }^{a}$ Values expressed are means \pm S.D. of three parallel measurements. The IC50 values were obtained by the linear regression analysis.

Table 3 shows $\beta$-carotene/lineloic acid assay of ethanol extracts of $A$. orientale. In $\beta$ carotene/lineloic acid assay, the aerial parts extract exhibited $71.29 \pm 0.19 \%$ inhibition against lipid peroxidation at $0.5 \mathrm{mg} / \mathrm{mL}$, while the bulb extract exhibited $52.47 \pm 0.32 \%$ at the same concentration. Both the extracts showed weak lipid peroxidation compared with BHT, but the aerial part extract indicated higher lipid peroxidation than ascorbic acid.

Table 3 - Antioxidant activity (\%) of the ethanolic extract of $A$. orientale in $\beta$-carotene-linoleic acid assay.

\begin{tabular}{lcccc}
\hline & \multicolumn{4}{c}{ Concentration $\mathbf{( m g / m L )}$} \\
\cline { 2 - 5 } Sample & $\mathbf{0 . 5}$ & $\mathbf{2 . 5}$ & $\mathbf{5}$ & $\mathbf{1 0}$ \\
\hline The extract of the aerial parts & $71.29 \pm 0.19^{\mathrm{a}}$ & $88.51 \pm 0.79$ & $88.86 \pm 0.76$ & $89.98 \pm 0.69$ \\
The extract of the bulbs & $52.47 \pm 0.32$ & $63.97 \pm 0.24$ & $64.61 \pm 0.24$ & $66.18 \pm 0.23$ \\
BHT & $95.7 \pm 0.1$ & - & - & - \\
Ascorbic acid & $63.69 \pm 3.24$ & - & - & - \\
\hline
\end{tabular}

${ }^{a}$ Values expressed are means \pm SD of three parallel measurements.

The total phenolic contents in the aerial parts extract using Folin-Ciocalteu's reagent was $120.979 \pm 1.05 \mathrm{mg} \mathrm{GAE} / \mathrm{g}$. On the other hand, ethanol extract of $A$. orientale bulbs had less phenolic contents $(35.664 \pm 0.21 \mathrm{mg} \mathrm{GAE} / \mathrm{g})$. The quantitative analysis of the phenolic compounds found in $A$. orientale ethanol extracts was performed using RP-HPLC, which allowed the separation of ten components (Table 4).

Table 4 showed that seven compounds were in the ethanol extract of $A$. orientale aerial parts. (+)catechin, apigenin and caffeic acid were the most abundant in this extract, with the content of 0.148 $\pm 0.0028,0.136 \pm 0.0032$ and $0.124 \pm 0.008 \mathrm{mg} / \mathrm{g}$, respectively. In addition, protocatechuic acid
$(0.096 \pm 0.004 \mathrm{mg} / \mathrm{g})$ and chlorogenic acid $(0.092$ $\pm 0.0064 \mathrm{mg} / \mathrm{g}$ ) were found in moderate amount. (-)-epicatechin and ferulic acid were found in low amounts $(0.068 \pm 0.002$ and $0.044 \pm 0.0028 \mathrm{mg} / \mathrm{g}$ respectively) whereas p-hydroxy benzoic acid, benzoic acid and rosmarinic acid were not detected.

Six phenolic compounds were identified in the bulb exract in which caffeic acid $(0.176 \pm 0.008$ $\mathrm{mg} / \mathrm{g}$ ) was in highest amount whereas (-)epicatechin $(0.096 \pm 0.002 \mathrm{mg} / \mathrm{g})$, chlorogenic acid $(0.076 \pm 0.0064 \mathrm{mg} / \mathrm{g})$, apigenin $(0.044 \pm 0.0032$ $\mathrm{mg} / \mathrm{g}$ ) were found in a moderate amount. Ferulic acid and protocatechuic acid were found in low amounts $(0.0016 \pm 0.0008$ and $0.0012 \pm 0.0004$ 
$\mathrm{mg} / \mathrm{g}$ respectively) whereas (+)-catechin, phydroxy benzoic acid, benzoic acid and rosmarinic acid were not detected. Prakash et al. (2007) have reported gallic acid, ferulic acid, protocatechuic acid, quercetin and kaempferol in different varieties of A. cepa from India.

Table 4 - Phenolic compounds in A. orientale ethanolic extracts.

\begin{tabular}{|c|c|c|}
\hline \multirow{2}{*}{$\begin{array}{l}\text { Phenolic } \\
\text { compound }\end{array}$} & \multicolumn{2}{|c|}{ Concentrations (mg/g extract) } \\
\hline & Aerial parts & Bulb \\
\hline $\begin{array}{l}\text { Protocatechuic } \\
\text { acid }\end{array}$ & $0.096 \pm 0.004^{\mathrm{a}}$ & $0.012 \pm 0.0004$ \\
\hline (+)-Catechin & $0.148 \pm 0.0028$ & NT \\
\hline $\begin{array}{l}\text { p-hydroxy } \\
\text { benzoic acid }\end{array}$ & NT & NT \\
\hline Chlorogenic acid & $0.092 \pm 0.0064$ & $0.076 \pm 0.0064$ \\
\hline Caffeic acid & $0.124 \pm 0.008$ & $0.176 \pm 0.008$ \\
\hline (-)-Epicatechin & $0.068 \pm 0.002$ & $0.096 \pm 0.002$ \\
\hline Ferulic acid & $0.044 \pm 0.0028$ & $0.016 \pm 0.00008$ \\
\hline Benzoic acid & NT & NT \\
\hline Rosmarinic acid & NT & NT \\
\hline Apigenin & $0.136 \pm 0.0032$ & $0.044 \pm 0.0032$ \\
\hline
\end{tabular}

Among the identified components, (+)-catechin, apigenin and caffeic acid have been reported for their antioxidant activity (Gulcin 2006; Sharififar et al. 2009). The ethanolic extracts, which were tested at three different concentrations, including $2.5,1.25$ and $0.625 \mathrm{mg} /$ plate did not show any mutagenic effect in the mutagenicity assays performed with S. typhimurium TA98 and TA100 (data was not shown). Similar results have been previously reported indicating the mutagenic activity of onion and onion's organosulphur compounds (Shon et al. 2004; Llana-Ruiz-Cabello et al. 2015). The antimutagenic activity of $A$. orientale ethanol extracts against 4-NPD and $\mathrm{NaN}_{3}$ was evaluated by the means of the Ames test using two strains of $S$. typhimurium, i.e TA98 and TA100. The results were evaluated by using standard plate incorporation method and summarized in Table 5. The extracts did not inhibit the mutagenicity of sodium azide in $S$. typhimurium TA100. The results of the present study showed that the extracts only exhibited antimutagenic activity against $S$. typhimurium TA98, which had a frameshift mutation. In the case of TA 98, a strong inhibitory effect was shown by aerial parts extract at $2.5 \mathrm{mg} /$ plate only. The same extract showed moderate inhibition at $1.25 \mathrm{mg} /$ plate and no inhibitory effect at 0.625 $\mathrm{mg} / \mathrm{plate}$. The bulb extract showed the moderate inhibition at $2.5 \mathrm{mg} / \mathrm{plate}$ and no inhibitory effects at 1.25 and $0.625 \mathrm{mg} / \mathrm{plate}$. In addition, no extracts showed any antimutagenic activity against $S$. typhimurium TA100 at the tested concentrations.

Table 5 - The antimutagenicity assay results of the ethanolic extracts of A.orientale .

\begin{tabular}{|c|c|c|c|c|c|}
\hline \multirow{3}{*}{ Test items } & \multirow{3}{*}{$\begin{array}{c}\text { Concentration } \\
\text { (mg/plate) }\end{array}$} & \multicolumn{4}{|c|}{ Number of revertants } \\
\hline & & \multicolumn{2}{|c|}{ TA98 } & \multicolumn{2}{|c|}{ TA100 } \\
\hline & & Mean \pm S. error & Inhibition \% & Mean \pm S. error & Inhibition \% \\
\hline Negative control & & $7.4 \pm 2.30^{b}$ & - & $15.75 \pm 4.11$ & - \\
\hline $4-N P D^{a}$ & 3 & $401.6 \pm 4.50$ & - & - & - \\
\hline $\mathrm{NaN}_{3}{ }^{\mathrm{a}}$ & 8 & - & - & $430 \pm 19.07$ & - \\
\hline \multirow{3}{*}{$\begin{array}{l}\text { Extract of the } \\
\text { aerial parts }\end{array}$} & 2.5 & $134 \pm 8.33$ & 66.63 & $328.3 \pm 30.85$ & 23.64 \\
\hline & 1.25 & $248.8 \pm 46.69$ & 38.05 & $374.3 \pm 29.70$ & 12.94 \\
\hline & 0.625 & $338.25 \pm 18.64$ & 15.78 & $421 \pm 2.64$ & 2.09 \\
\hline Extract of the & 2.5 & $280 \pm 24.43$ & 30.29 & $338.5 \pm 17.52$ & 21.27 \\
\hline \multirow[t]{2}{*}{ bulb } & 1.25 & $334.83 \pm 12.05$ & 16.63 & $380.6 \pm 8.38$ & 11.47 \\
\hline & 0.625 & $373 \pm 19.65$ & 7.13 & $396.3 \pm 7.09$ & 7.82 \\
\hline
\end{tabular}

${ }^{\mathrm{a}} 4-\mathrm{NPD}$ and $\mathrm{NaN}_{3}$ were used as positive controls for $S$. typhimurium TA98 and TA100 strains, respectively.

${ }^{\mathrm{b}}$ Values expressed are means \pm S.D. of three parallel measurements. The regression analysis was carried out in Microsoft Excel between percent inhibition of mutagenicity and log values of concentrations of the plant extract.

\section{CONCLUSION}

The ethanolic extract of the aerial parts of $A$. orientale exhibited high antimicrobial and antibiofilm activities. Results clearly indicated that the aerial parts extract possessed high ability to scavenge the DPPH and hydroxyl radicals and that the phytochemicals present in A. orientale aerial parts extract had potent antioxidant activity in positive correlation with total phenolic content. All the extracts of $A$. orientale could be considered 
genotoxically safe at the tested concentrations. The Ames test revealed that the aerial parts extract exhibited an antimutagenic activity against $S$. typhimurium TA98. Hence, potential therapeutic compounds isolated from the aerial parts of $A$. orientale could be preferred as a preventive medication against cancer and in the treatment of bacterial diseases.

\section{ACKNOWLEDGEMENTS}

Authors thank Ass. Prof. Dr. M.D. Sahin, Botanist, Usak University, Usak, Turkey, for providing plant taxonomic identification.

\section{REFERENCES}

Ames BN, Shigenaga MK, Hagen TM. Oxidants, antioxidants, and the degenerative diseases of aging. Proc Natl Acad Sci. U.S.A. 1993; 90: 7915-7922.

Bakht J, Khan S, Shafi M. In vitro antimicrobial activiy of Allium cepa (dry bulbs) against Gram positive and Gram negative bacteria and fungi. Pak J Pharm Sci. 2014; 27: 139-145.

Bernaert N, De Paepe D, Bouten C, De Clercq H, Stewart D, Van Bockstaele E, et al. Antioxidant capacity, total phenolic and ascorbate content as a function of the genetic diversity of leek (Allium ampeloprasum var. porrum). Food Chem. 2012; 134: 669-677.

Boffetta P, Couto E, Wichmann J, Ferrari P, Trichopoulos D, Bueno-de-Mesquita HB, et al. Fruit and vegetable intake and overall cancer risk in the european prospective investigation into cancer and nutrition (EPIC). J Natl Cancer Inst. 2010; 102: 529537.

Caponio F, Alloggio V, Gomes T. Phenolic compounds of virgin olive oil: influence of paste preperation techniques. Food Chem. 1999; 64: 203-209.

Ceylan O. Antibiofilm, mutagenic and antimutagenic activiy of Allium sphaerocephalon L. J Pure Appl Microbiol. 2014; 8: 2879-2885.

Chandler SF, Dodds JH. The effect of phosphate, nitrogen and sucrose on the production of phenolics and solasidine in callus cultures of Solanum lacinitum. Plant Cell Rep. 1983; 2: 105-108.

CLSI-Clinical and Laboratory Standards Institute. Performance standards for antimicrobial susceptibility testing. Sixteenth Informational Supplement. Document M100-S16, Wayne, Pa. 2006.

Corzo-Martinez M, Corzo N, Villamiel M. Biological properties of onions and garlic. Trends in Food Sci Tech. 2007; 18: 609-625.
Davis PH. Flora of Turkey and the East Aegean Islands, Vol. 8. Edinburgh, UK: Edinburgh University Press, 1984, 203-204

Dziri S, Hassen I, Fatnassi S, Mrabet Y, Casabianca H, Hanchi B, et al. Phenolic constituents, antioxidant and antimicrobial activities of rosy garlic (Allium roseum var. odoratissimum). J Func Foods. 2012; 4: 423-432.

Eker I, Koyuncu M. Allium olivieri Boiss. (Alliaceae), a new taxon to Turkey, with contributions to its taxonomy. Acta Soc Bot Pol. 2011; 80: 275-277.

Evandri MG, Battinelli L, Daniele C, Mastrangelo S, Bolle P, Mazzanti G. The antimutagenic activity of Lavandula angustifolia (lavender) essential oil in the bacterial reverse mutation assay. Food Chem Toxicol. 2005; 43: 1381-1387.

Genc I, Ozhatay FN. Allium efeae (Amaryllidaceae), a new species from northwest Anatolia, Turkey. Turk $J$ Bot. 2014; 38: 1022-1025.

Gulcin I. Antioxidant activity of caffeic acid (3,4dihydroxycinnamic acid). Toxicology. 2006; 217: 213-220.

Guner A, Ozhatay N, Ekim T, Baser KHC. Flora of Turkey and the East Aegean islands, Vol. 11. (Suppl 2)., Edinburgh, UK: Edinburgh University Press, 2000 .

Hannan A, Humayun T, Hussain MB, Yasir M, Sikandar S. In vitro antibacterial activity of onion (Allium cepa) against clinical isolates of Vibrio cholerae. J Ayub Coll Abbottabad. 2010; 22(2): 160163.

Iciek M, Kwiecieri I, Wlodek L. Biological properties of garlic and garlic-derived organosulfur compounds. Environ Mol Mutagen. 2009; 50: 247-265.

Ikken Y, Morales P, Maetinez A, Marin ML, Haza AI, Cambero MI. Antimutagenic effect of fruit and vegetable ethanolic extracts against $\mathrm{N}$-nitrosamines evaluated by the Ames test. J Agric Food Chem. 1999; 47: 3257-3264.

Islam MS, Kusumoto Y, Al-Mamun, MA. Cytotoxicity and Cancer (HeLa) Cell Killing Efficacy of Aqueous Garlic (Allium sativum) Extract. J Sci Res. 2011; 3(2): 375-382.

Ismail S, Jalilian FA, Talebpour AH, Zargar M, Shameli K, Sekawi Z, et al. Chemical composition and antibacterial and cytotoxic activities of Allium hirtifolium Boiss. Biomed Res Int. 2013; ID 696835,1-8.

Jayaprakasha GK, Jaganmohan Rao, L. Phenolic constituents from lichen Parmotrema stuppeum (Nyl.). Hale and their antioxidant activity. Z Naturforsch C. 2000; 55: 1018-1022.

Karuppiah P, Rajaram S. Antibacterial effect of Allium sativum cloves and Zingiber officinale rhizomes against multiple-drug resistant clinical pathogens. Asian Pac J Trop Biomed. 2012; 2: 597-601. 
Lau BHS. Suppression of LDL oxidation by garlic compounds is a possible mechanism of cardiovascular health benefit. J Nutr. 2006; 136: 765768.

Lazarevic JS, Dordevic AS, Zlatkovic BK, Radulovic NS, Palic RM. Chemical composition and antioxidant and antimicrobial activites of essential oil of Allium sphaerocephalon L. subsp. sphaerocephalon (Liliaceae) inflorescences. J Sci Food Agric. 2011; 91: 322-329.

Llana-Ruiz-Cabello M, Maisanaba S, Gutierrez-Praena D, Prieto AI, Pichardo S, Jos A, et al. Cytotoxic and mutagenic in vitro assessment of two organosulfur compounds derived from onion to be used in the food industry. Food Chem. 2015; 166: 423-431.

Maron DM, Ames BN. Revised methods for the Salmonella mutagenicity test. Mutat Res. 1983; 113: 173-215.

Merritt JH, Kadouri DE, O'Toole GA. Growing and analyzing static biofilms. Curr Protoc Microbiol. 2005; 1:1-3.

Mortelmans K, Zeiger E. The Ames Salmonella/microsome mutagenicity assay. Mutat Res. 2000; 455: 29-60.

Najjaa H, Zerria K, Fattouch S, Ammar E, Neffati M. Antioxidant and antimicrobial activities of Allium roseum L. "Lazoul" a wild edible endemic species in North Africa. Int J Food Prop. 2011; 14: 371-380.

Negi PS, Jayaprakash GK, Jena BS. Antioxidant and antimutagenic activities of pomegranate peel extracts. Food Chem. 2003; 80: 393-397.

Nencini C, Menchiari A, Franchi Gian G, Micheli L. In vitro antioxidant activity of aged extracts of some Italian Allium species. Plant Food Hum Nutr. 2011; 66: $11-16$

Nidadavolu P, Amor W, Tran PL, Dertien J, ColmerHamood JA, Hamood AM. Garlic ointment inhibits biofilm formation by bacterial pathogens from burn wounds. J Med Microbiol. 2012; 61: 662-671.

Oh HT, Kim SH, Choi HJ, Chung MJ, Ham SS. Antioxidative and antimutagenic activities of $70 \%$ ethanol extract from masou salmon (Oncorhynchus masou). Toxicol In Vitro. 2008; 22: 1484-1488.

PFAF, Plants For A Future. [Internet] England and Wales: c1996-2012 [cited 2014 Dec 26] Available from: http://www.pfaf.org/user/ Plant.aspx ?LatinName=Allium+orientale.

Prakash D, Singh BN, Upadhyay G. Antioxidant and free radical scavenging activities of phenols from onion (Allium cepa). Food Chem. 2007; 102: 13891393.

Redzic S, Pilipovic S, Pilav E. Comparative analysis of antimicrobial activity of fresh extracts of certain species of genus Allium L. (Alliaceae). Planta Med. 2008; 8: 74-91

Rezgui A, Mitaine-Offer AC, Paululat T, Delemasure S, Dutartre P, Lacaille-Dubois MA. Cytotoxic steroidal glycosides from Allium flavum. Fitoterapia. 2014; 93: 121-125.

Rouis-Soussi LS, Boughelleb-M'Hamdi N, El AyebZakhama A, Flamini G, Jannet HB, Harzallah-Skhiri F. Phytochemicals, antioxidant and antifungal activities of Allium roseum var. grandiflorum subvar. typicum Regel. S Afr J Bot. 2014; 91: 63-70.

Santana-Rios G, Orner GA, Amantana A, Prowost C, $\mathrm{Wu}$ SY, Dashwood, RH. Potent antimutagenic activity of white tea in the Salmonella assay. Mutat Res. 2001; 495: 61-74.

Sharififar F, Dehghn-Nudeh G, Mirtajaldini M. Major flavanoids with antioxidant activity from Teucrium polium L. Food Chem. 2009; 112: 885-888.

Shon MY, Choi SD, Kahng GG, Nam, SH, Sung NK. Antimutagenic, antioxidant and free radical scavenging activity of ethyl acetate extracts from white, yellow and red onions. Food Chem Toxicol. 2004; 42: 659-666.

Simin N, Orcic D, Cetojevic-Simin D, Mimika-Dukic N, Anackov G, Beara I, et al. Phenolic profile, antioxidant, anti-inflammatory and cytotoxic activities of small yellow onion (Allium flavum $\mathrm{L}$. subsp. flavum, Alliaceae). LWT-Food Scl Technol. 2013; 54: 139-146.

Slinkard K, Singleton VL. Total phenol analyses: automation and comparison with manual methods. Am J Enol Viticult. 1977; 28: 49-55.

Stajner D, Popovic B, Čanadanovic-Brunet J, Stajner M. Antioxidant and scavenger activities of Allium ursinum. Fitoterapia. 2008; 79: 303-305.

Tapsell LC, Hemphill I, Cobiac L, Patch CS, Sullivan DR, Fenech M, et al. Health benefits of herbs and spices: the past, the present, the future. Med J Aust. 2006; 185: 4-24

Tepe B, Sokmen M, Akpulat HA, Sokmen A. In vitro antioxidant activities of the methanol extracts of five Allium species from Turkey. Food Chem. 2005; 92: 89-92.

Timite G, Mitaine-Offer AC, Miyamoto T, Tanaka C, Mirjolet JF, Duchamp O, et al. Structure and cytotoxicity of steroidal glycosides from Allium schoenoprasum. Phytochemistry. 2013; 88: 61-66.

Yamasaki K, Hashimoto A, Kokusenya Y, Miyamoto T, Sato T. Electrochemical method for estimating the antioxidative effects of methanol extracts of crude drugs. Chem Pharm Bull. 1994; 42: 1663- 1665.

Yeh YY, Yeh SM. Homocysteine-lowering action is another potential cardiovascular protective factor of aged garlic extract. J Nutr. 2006; 136: 745-749.

Yu Z, Xu M, Santana-Rios G, Shen R, Izquierdo-Pulido $\mathrm{M}$, Williams DE, et al. A comparison of whole wheat, refined wheat and wheat bran as inhibitors of heterocyclic amines in the Salmonella mutagenicity assay and in the rat colonic abberant crypt focus assay. Food Chem Toxicol. 2001; 39: 655-665. 